\title{
Pengaruh Model Pembelajaran Take and Give Berbantuan Media Question Card Terhadap Kompetensi Pengetahuan PPKn
}

\author{
I Wayan Agus Juliarta1*, Made Putra², I Gusti Agung Oka Negara3 \\ 123 Program Studi S1 Bimbigan dan Konseling FKIP - Universitas Kristen Satya Wacana
}

\begin{abstract}
Abstrak
Rendahnya kompetensi pengetahuan PPKn siswa yang disebabkan oleh kurang optimalnya penggunaan model pembelajaran yang inovatif dan kreatif serta kurangnya penggunanan media pembelajaran. Tujuan dilaksanakan penelitian ini untuk menganalisis pengaruh yang signifikan model pembelajaran Take and Give berbantuan media Question Card terhadap kompetensi pengetahuan PPKn siswa kelas V SD. Jenis Penelitian yang dilakukan adalah kuantitatif dengan desain Eksperimen semu dan rancangannya non equivalen control group. Populasinya seluruh kelas $\mathrm{V}$ yang terdiri dari 11 kelas dengan dua sampel penelitian diambil dengan cara random sampling terdapat sampel eksperimen yang diterapkan model Take and Give berbantuan Question Card untuk kelas V SD 18 sebanyak 39 siswa dan kelas V Sd 2. sebanyak 39 siswa sebagai kontrol yang dibelajarkan secara konvensional. Pengumpulan datanya menggunakan metode tes berupa tes objektif pilihan ganda biasa. Setelah dilakukan penelitian menunjukakan adanya perbedaan kompetensi pengetahuan PPKn kedua kelompok. Terbukti dari nilai rata - rata kelompok eksperimen yaitu $\overline{\mathrm{X}}=0,733$ lebih dari kelompok kontrol $\overline{\mathrm{X}}=0.445$. dan setelah dianalisis menggunakan t-test dengan rumus polled varians. Diperoleh ananlisis datanya (thitung=8,835 $>$ ttabel $=1,992)$ dengan alpha $5 \%$ dan $(\mathrm{dk}=39+39$ $2=76$ ) maka penolakan Ho dan penerimaan Ha yang berarti adanya perbedaan yang signifikan antar kedua kelompok sampel. Maka dari itu dengan penerapan model Take and Give berbantuan media Question Card memberi Pengaruh Pada Kompetensi Pengetahuan PPKn kelas V SD.
\end{abstract}

Kata Kunci:

Take and Give, Question Card, PPKn

\begin{abstract}
This research is quantitative research with quasi-experimental design and non-equivalent control group design. The population of this research is 5 th grade students of letda made putra cluster which consists of eleven class with two sample that is chosen by using cluster random sampling. The Take and Give model Question Card based is applied for the experiment sample which is consisted of 39 students of 5th grade students in SD 18. 39 students of 5th grade students in SD 2 is chosen as the control group which is taught conventionally. The data collection method is using the objective test. The result of the research shows that there are competency differences between two groups. It shows from the average score between two group which the score of the experimental group $(\bar{X}=0,733)$ is higher than the control group $(\bar{X}=$ $0,455)$. The calculation of t-test using variant polled formula shows that (thitung=8,835 $>$ ttabel $=1,992$ with $5 \%$ of alpha and $\mathrm{dk}=39+39-2=76$ ) the Ho is declined and Ha is accepted. It means that there is significant difference between two groups. In conclusion, through implementation of Take and Give model Question Card based gives significant effect towards 5th grade students' competency in SD.
\end{abstract}

Keywords:

Take and Give Model, Question Card. Civic Education Compete 


\section{PENDAHULUAN}

Kompetensi adalah perpaduan antara pengetahuan, sikap serta keterampilan untuk mengukur keaktifan belajar peserta didik yang mengandung ranah kognitif, sikap, dan keterampilan dalam proses pembelajaran. Menurut (Kosasih, 2016) aspek yang terkandung dalam kompetensi ialah sikap, pengetahuan dan keterampilan yang didalamnya termuat mental dan fisik siswa, kompetensi ialah suatu kesatuan yang mamuat banyak aspek ranah dengan demikian kompetensi merupakan perpaduan antara beberapa aspek seperti sikap, pengetahuan dan keterampilan untuk referensi pada peningkatan kurikulum agar terwujudnya tujuan pendidikan nasional. Selain itu (Wiyasa, 2015) menyatakan PPKn merupakan salah satu mata pelajaran yang sering muncul dalam kegiatan pembelajaran untuk mengembangkan nilai, sikap dan kepribadian yang sesuai dengan Pancasila, UUD 1945, cinta tanah air, dan berwawasan kebangsaan.

PPKn merupakan suatu upaya agar dapat mengatur masyarakat sebagai negara demokratis, mempunyai rasa cinta tanah air dan displin menciptakan kehidupan yang harmonis berlandaskan nilai nilai Pancasila. Menurut (Rahayu, 2018) menyatakan bahwa PPKn ialah belajar mengenai aktivitas dalam kehidupan sehari - hari mengajari cara untuk menaati nilai nilai Pancasila merupakan dasar negara Indonesia. Menurut (Darmadi, 2015) menyatakan bahwa, PPKn ialah suatu cara untuk menyatukan individu - individu supaya menjunjung serta memmperkuat kelompok politik, selama kelompok politik tersebut merupakan keputusan bersama. Dengan demikian PPKn meriupakan suatu cara belajar yang mempunyai tujuan menyiapakan siswa untuk berpikir kritis serta berperilaku demolkratis dan cara mengajaricara untuk menaati nilai - nilai Pancasila adalah dasar negara Indonesia.

Mengajarkan PPKn di Sd ialah untuk memberikan pengetahuan serta menyadarkan siswa untuk mengisi kemerdekaan dengan cara membangun, mempertahankan kemerdekaan serta mempersiapkan makna perjuangan yang dilakukan oleh para pejuan kemerdekaan.

Sesuai dengan pemaparan diatas maka dapat dirangkum, kompetensi pengetahuan PPKn adalah kemapuan peserta didik untuk mencapai standar kelulusan PPKn setelah mengalami proses belajar yang mempunyai tujuan menyiapkan siswa berpikir kritis serta berperilaku demikratis serta mengajri cara untuk menaati nilai - nilai Pancasila adalah Dasar Negara Indonesia.

Pembelajaran PPKn semestinya bisa menciptakan murid tidak pasif lagi di kelas saat proses penelaahan, dalam pembelajaran di kelas justru hanya berpusat pada guru dan hanya pada pengajaran menghafal tanpa adanya kebermaknaan dari konsep tersebut. Saat menjelaskan pelajaran pendidik tidak memakai suatu model dan media yang kreatif, guru cenderung memberikan presentasi secara lisan menyebabkan kejenuhan para murid saat pelajaran. (Sari dan Tarigan, 2017) berpendapat kurangnya penerapan variasi model penelahaan yang diterapkan oleh pendidik mengakibatkan siswa diam saja sewaktu belajar. Hal ini bisa dilihat saat banyak anak didik yang berbicara bukan mengenai materi pelajaran dengan temannya serta tidak fokus saat belajar.

Berdasarkan hasil observasi yang dilakukan pada tanggal 29- 28 Oktober 2019 diperoleh data berupa nilai Penilaian Tengah Semester (PTS) ganjil tahun Ajaran 2019/2020 pada pelajaran PPKn yang belum memuaskan. Diketahui dari 409 siswa sebanyak 50,80 \% masih berada dibawah KKM, Berbagai faktor yang menyebabkan rendahnya kompetensi pengetahuan PPKn siswa yaitu faktor internal dan faktor eksternal. Faktor internal merupakan faktor yang bersumber dari luar diri peserta didik yaitu keluarga, sekolah, dan masyarakat. Mencermati permasalahan belajar yang diuraikan di atas, dalam penelitian ini diterapkan sebuah inovasi baru yaitu menerapkan model dalam pembelajaran. sehingga proses pembelajaran PPKn berjalan secara optimal. Model tersebut adalah model Take and Give. Model Take and Give adalah model pembelajaran yang menyenangkan untuk digunakan dalam proses mengajar sehingga menciptakan situasi yang aktif dan kondusif dalam proses pembelajaran. (Huda, 2013) menyatakan model pembelajaran Take and Give adalah pembelajaran yang dibantu oleh penyajian data yang diawali dengan pemberian kartu kepada siswa. (Udayantri, 2017) Menyatakan dalam pembelajaran kooperatif tipe Take and Give ini siswa diajak untuk berfikir dalam menyelesaikan tugas yang telah diberikan oleh guru. Selain itu (Parlina, 2017) menyatakan Model pembelajaran take and give adalah model pembelajaran dimana siswa mengambil dan memberi pelajaran pada siswa yang lainnya. Beberapa ahli percaya bahwa suatu mata pelajaranbenar-benar dikuasai banyak apabila peserta didik mampu mengajarkan pada peserta lain. Catatan kecil yang terdapat pada kartu, haruslah dikuasai peserta didik, peserta didik kemudian mencari pasangan nya untuk bertukar pengetahuan sesuai apa yang di dapatnya di kartu, kemudian diakhir pembelajaran dievaluasi. komponen penting dalam pembelajaran Take and Give ialah materi harus dikuasai yang terdapat pada kartu kemudian bekerjasama secara berpasangan. Kemampuan mengkomunikasikan materi yang terdapat pada kartu serta evaluasi untuk mengetahui sejauh mana penguasaan siswa terhadap materi dari kartu yang Peserta Didik miliki dan materi dari kartu yang berasal dari temannya. Suparno Dalam (Shoimin, 2014) mendidik tidak sekedar mentransfer 
pengetahuan dari pendidik ke peserta didik. Peran pendidik dalam proses pembelajaran Take and Giev lebih menuju sebagai mediator dan fasilitator. (Lantanida, 2014) Model pembelajaran Take and Give adalah pembelajaran yang yang dibuat dari kelompok kecil untuk mencapai tujuan bersama. Agar tujuan dari proses pembelajaran tercapai, perlu dibuatkan suatu pendekatan dalam pembelajaran yang bisa mengaitkan materi teori dengan kenyataan yang ada dilingkungan sekitarnya. Selain itu siswa menjadi lebih aktif saat belajar dan ingatan siswa menjadi lebih kuat. (Yuliastini, 2015) Take and Give diartikan saling memberi dan saling menerima diantara siswa. Model pembelajaran kooperatif tipe Take and Giveadalah suatu tipe pembelajaran yang mengajak siswa untuk saling berbagi mengenai materi yang disampaikan oleh guru dengan kata lain tipe ini melatih siswa terlibat secara aktif dalam menyampaikan materi yang mereka terima kepada siswa lainnya dengan menggunakan media kartu yang di dalamnya terdapat catatan berupa materi pelajaran yang harus dipahami dan dihapalkan oleh siswa. (Theriana, 2019) Tipe Take and Give merupakan tipe pembelajaran yang memiliki tujuan untuk membangun suasana belajar yang dinamis, penuh semangat, dan antusiasme, serta menciptakan suasana belajar dari pasif ke aktif, dari jenuh menjadi riang, serta mempermudah siswa untuk mengingat materi.

Jadi dapat dirangkum Model pembelajaran Take and Give adalah suatu Model pembelajaran yang dimana peserta didik diajak saling berbagi dari materi yang disampaikan oleh pendidik, peserta didik dilatih untuk terlibat aktif dalam mengemukakan materi yang peserta didik terima dari pendidik kemudian peserta didik menyampaikan lagi ke teman - teman yang berada di kelasnya secara berulang ulang. Model Take and Give dapat membangun peserta didik dalam belajranya dari pasif ke aktif, Peserta didik lebih mudah mengingat pembelajaran yang diberikan, ini dapat dilihat dari pembelajarannya peserta didik lebih bisa mengingat pelajaran yang diberikan oleh teman sebayanya.

Sintak Pembelajaran Take and Give adalah : (a)Siapkan Media yang terbuat dari kartu, (b) Jelaskan materi sesuai tujuan pengajaran khusus. (c) Untuk memantapkan peserta tiap siswa di beri masing masing satu kartu untuk di pelajari (dihafal). Kartu di buat berukuran 10 x 15 centimeter sebanyak peserta didik. kartu diisi sub materi (yang beda dengan kartu yang lain nya. (d) Seluruh Peserta Didik di perintah mencari pasangan untuk saling memberi informasi. Tiap siswa harus mencatat nama pasangan nya pada kartu contoh. (e)Demikian hingga setiap siswa dapat saling memberi dan menerima materi masing - masing (Take and Give). (f)Untuk mengevaluasi keberhasilan, berikan siswa pertanyaan yang tak sesuai dengan kartunya. (g)Pendidik bersama Peserta Didik bertanya jawab, dan didini pendidik meluruskan kesalahan pemahaman dan memberi pemahaman. (h) Penyimpulan. Model ini mempunyai Kelebihan yaitu (a)Peserta didik lebih mudah mengerti pelajaran yang diberikan pendidik (b)Lebih Mudah Mengingat Pembelajaran (c) Motivasi, Partisipasi, minat saat belajarlebih meningkat.

Model pembelajaran Take and Give jika dipadukan dengan media question card akan membuat pelajaran menjadi lebih menarik. Media question card merupakan media kartu yang di dalam nya terdapat sebuah pesan dimana hal ini dapat merangsang siswa dalam proses pembelajaran (Arsyad, 2017). (Viani, 2017) berpendapat bahwa media question card dapat melatih konsentrasi serta fokus siswa dalam menangkap informasi yang terdapat dalam media question card. media question card memungkinkan siswa belajar lebih rileks dengan memainkan kartu soal, di samping menumbuhkan tanggung jawab, kerjasama, persaingan sehat, dan keterlibatan di dalam proses belajar(Ariswati, 2018).

Berdasarkan uraikan di atas dapat dirangkum bahwa model pembelajaran Take and Give berbantuan Media Question Card adalah suatu model pembelajran yang di mana dalam pelaksanaannya pendidik menyajikan Sebuah Kartu yang berisikan tentang soal - soal dan Materi pembelajaran yang di berikan ke masing - masing siswa kemudian setiap siwsa harus menghafal kertu yang di dapat oleh setiap siswa tujuannya untuk melatih keaktifan, ketajaman berpikir peserta didik dan dapat membuat peserta didik menjadi lebih mudah dalam bergaul dengan teman sebayanya..

\section{METODE PENELITIAN}

Metode penelitian ini menggunakan jenis penelitian quasi-eksperimental design atau eksperimen semu mempergunakan rancangan non equivalent pretest posttest control group design. Sugiyono (2018) quasi experimental design memiliki kelompok kontrol, tapi tidak memiliki fungsi penuh untuk mengendalikan variabel asing yang memengaruhi proses eksperimen. Hal tersebut disebabkan karena kesanggupan dalam mengamati perilaku maupun karakter siswa yang tidak mungkin paling utama ketika anak didik tidak berada di sekolah, penelitian ini juga tidak menuntut penguasaan dalam memahami pemahaman siswa terhadap perlakuan yang sudah dilakukan.

Menurut Sugiyono (2018) Populasi merupakan wilayah menyeluruh berisikan obyek/subyek yang memiliki ciri khas guna dipelajari kemudian dibuatkan kesimpulan oleh peneliti. Syahrun dan Salim (2014)lebih lanjut menjelaskan populasi yaitu seluruh objek yang diteliti lalu dirangkum berupa kuantitatif ataupun kualitatif. Populasi pelaksanaan penelitian ini yaitu siswa kelas V di SD Negeri Gugus 
Letda Made Putra Kecamatan Denpasar Utara Tahun Ajaran 2019/2020 sebanyak 11 kelas dengan jumlah 4099 siswa. Setelah menentukan populasi penelitian maka langkah selanjutnya yaitu menentukan sampel. Menurut Sugiyono (2018) Sampel memiliki makna suatu ciri khas tertentu yang dimiliki oleh populasi. Teknik Cluster Random Sampling dipakai saat pengambilan sampel penelitian. Untuk menemukan kelas yang setara dari segi akademisi, diberikan pretest untuk sampel. Uji t ialah teknik yang digunakan untuk menganalisa data pretest, sebelumnya mesti mencukupi kriteria untuk uji normalitas dan uji homogenitas. Setelah melakukan uji kesetaraan dan kedua kelompok dinyatakan setara maka dilanjutkan dengan mengundi kedua kelompok tersebut untuk penentuan kelas eksperimen dan kelas kontrol. Dari hasil pengundian kelas Va SD Negeri 2 Dangin Puri sebagai regu eksperimen dan kelas Vb SD Negeri 18 Dangin Puri sebagai regu kontrol.

Metode pengumpulan data yang dipakai dalam penelitian ini adalah metode tes. Instrumen yang digunakan adalah instrument kompetensi pengetahuan PPKn berupa soal objektif pilihan ganda biasa dikumpulkan melalui tes. Suatu alat yang dipakai untuk mengasah suatu fenomena alam atau sosial yang diteliti atau diobservasi merupakan instrument penelitian (Sugiyono, 2018). Tes yang berjumlah sebanyak 40 soal tersebut mempunyai empat pilihan jawaban yaitu A,B,C,D. setiap butir item diberi skor 1 bila betul dan diberi skor 0 bila salah. Dari 40 soal tersebut memuat indikator yang berpedoman pada kompetensi kognitif IPA yaitu dari C1-C4. Penyusunan tes berdasarkan pada kompetensi dasar (KD) dan indikator yang sesuai dengan materi pelajaran. Adapun KD dan indikator yang digunakan untuk penyusunan instrumen disajikan pada tabel 01 berikut.

Tabel 1. Penyusunan Kompetensi Dasar dan Indikator Instrumen Kompetensi Pengetahuan IPA.

\begin{tabular}{|c|c|c|}
\hline $\begin{array}{l}\text { Kompetensi Dasar } \\
\text { (KD) }\end{array}$ & Indikator & Tipe Kognitif \\
\hline \multirow{8}{*}{$\begin{array}{l}\text { Menganalisis } \\
\text { Pengaruh kalor } \\
\text { terhadap perubahan } \\
\text { suhu dan wujud } \\
\text { benda } \\
\text { kehidupan } \\
\text { sehari }\end{array}$} & Mendefinisikan pengertian kalor dan suhu. & $\mathrm{C} 2$ \\
\hline & Menyebutkan macam - macam perubhan wujud benda & $\mathrm{C} 1$ \\
\hline & $\begin{array}{l}\text { Mengidentifikasi jenis - jenis perpindahan kalor dalam } \\
\text { kehidupan sehari - hari }\end{array}$ & $\mathrm{C} 2$ \\
\hline & Mengidentifikasi pengertian benda penghantar panas. & $\mathrm{C} 2$ \\
\hline & Mengidentifikasi peristiwa perubhan wujud benda & $\mathrm{C} 4$ \\
\hline & $\begin{array}{l}\text { Mengklasfikasikan benda - benda sekitar berdasarkan jenis } \\
\text { penghantar panasnya. }\end{array}$ & $\mathrm{C} 3$ \\
\hline & Mengaitkan kalor dengan perubahan wujud benda & $\mathrm{C} 3$ \\
\hline & Menyebutkan sifat - sifat benda (padat, cair, gas) & $\mathrm{C} 1$ \\
\hline
\end{tabular}

Setelah itu dilakukan pengujian instrument. Sebelum diujikan, terlebih dahulu dilakukan validitas isi dan validitas teoritik kemudian diujicoba sebanyak 50 butir soal. Uji validitas isi dilakukan dengan pengujian langsung kepada judges. Sedangkan uji validitas butir tes menggunakan uji validitas, daya pembeda, tingkat kesukaran dan reliabilitas. Banyak butir tes yang memenuhi syarat pada uji coba sebanyak 30 butir tes. Jadi, instrumen yang dipergunakan saat penelitian ini tervalidasi dan reliabel.

Metode analisis data yang digunakan adalah statistik deskriptif dan statistik inferensial. Statistik deskriptif dipakai untuk menganalisisa data dengan mendeskripsikan data yang sudah terhimpun. Statistik deskriptif berupa rata-rata (mean), standar deviasi, variansi, skor terendah dan skor tertinggi. Sedangkan statistik inferensial digunakan untuk pengjian hipotesis yang diajukan melalui uji-t polled varians. Namun sebelum itu dilakukan terlebih dahulu uji prasayarat yakni uji normalitas data menggunakan uji Kolmogorov-Smirnov dan uji homogenitas dengan uji F (Fisher).

\section{ANALISIS DAN PEMBAHASAN}

Berdasarkan uji hipotesis diperoleh $t_{h i t}=8,835$ sedangkan pada taraf alpha 0,05 dengan dk $=76$ diperoleh nilai $t_{t a b}=1,992$ sehingga $t_{h i t}=8,835>t_{t a b}=1,992$. Dengan demikian, hipotesis nol $\left(H_{0}\right)$ ditolak. Hal ini menunjukkan bahwa terdapat perbedaan yang signifikan Kompetensi Pengetahuan antara kelompok siswa yang dibelajarkan dengan Model Take and Give Berbantuan Media Question Card dengan kelompok siswa yang dibelajarkan dengan model pembelajaran konvensional pada siswa kelas V SD N Gugus Ledta Made Putra Tahun Ajaran 2019/2020. 
Perbedaan signifikan Kompetensi Pengetahuan dalam pembelajaran PPKn antara kelompok yang dibelajarkan menggunakan Model Take and Give Berbantuan Media Question card dengan kelompok yang dibelajarkan menggunakan pembelajaran konvensional dapat dilihat dari perbedaan hasil analisis rerata GnS ternormalisasi Kompetensi Pengetahuan dalam pembelajaran PPKn . Rerata GnS kelompok eksperimen $\overline{\mathrm{X}}=0,733$ lebih dari rerata $G n S$ kelompok kontrol $\overline{\mathrm{X}}=0,445$.

Perbedaan hasil penguasaan Kompetensi Pengetahuan dengan perolehan nilai rerata yang lebih tinggi pada kelompok eksperimen dibandingkan kelompok kontrol disebabkan oleh perlakuan berupa Model Take and Give Berbantuan Media Question Card yang diberikan pada kelompok eksperimen.

Pertama, model pembelajaran Take and Give berdampak pada kompetensi pengetahuan PPKn karena dapat meningkatkan kemampuan berpikir siswa karena bisa bertukar pikiran dengan teman sebayanya, dapat mengerjakan tugas dengan cepat dan tepat. Pada proses ini peserta didik secara langsung mengembangkan interaksi sosial dengan teman sebayanya, yaitu saling berdiskusi memecahakn permasalahan yang diberikan oleh guru. (Dewi, 2014) menyatakan model Take and Give (memberi dan menerima) diterapkan untuk melatih siswa menjadi narasumber dan mitra belajar bagi teman -teman yang lain, dengan saling bertukar pengetahuan yang dimiliki. Oleh karena itu setiap siswa dituntut untuk menguasai materi yang menjadi topik bahasannya dan mempunyai kemampuan berkomunikasi, sehingga ia dapat menyampaikan materi tersebut kepada siswa lain. Sedangkan siswa yang menerima informasi dituntut pula untuk dapat menangkap materi yang disampaikan kepadanya dengan baik. Karena ia pun harus mampu mengembangkan sebuah contoh yang relevan dengan materi yang diterimanya. (Exma, 2016) Model Take and Give peserta didik bukan hanya mempelajari materi yang diberikan oleh guru tetapi peserta didik juga dapat belajar melalui teman sehingga pengetahuan peserta didik menjadi bertambah dan hasil belajar peserta didik yang rendah juga dapat meningkat. Model pembelajaran Take and Give adalah suatu Model pembelajaran yang dimana peserta didik diajak saling berbagi dari materi yang disampaikan oleh pendidik, peserta didik dilatih untuk terlibat aktif dalam mengemukakan materi yang peserta didik terima dari pendidik kemudian peserta didik menyampaikan lagi ke teman - teman yang berada di kelasnya secara berulang - ulang. Model Take and Give dapat membangun peserta didik dalam belajranya dari pasif ke aktif, Peserta didik lebih mudah mengingat pembelajaran yang diberikan, ini dapat dilihat dari pembelajarannya peserta didik lebih bisa mengingat pelajaran yang diberikan oleh teman sebayanya. (Shoimin, 2014) menerangkan bahwa kelebihan metode pembelajaran Take and Give adalah sebagai berikut:1) Peserta didik akan lebih cepat memahami penguasaan materi dan informasi, karena mendapatkan informasi dari guru dan peserta didik yang lain, (2) Dapat menghemat waktu dalam pemahaman dan penguasaan peserta didik akan informasi, (3) Meningkatkan kemampuan untuk bekerja sama dan bersosialisasi, (4) Melatih kepekaan diri, empati melalui variasi perbedaan sikap dan tingkah laku selama bekerja, (5) Upaya mengurangi rasa kecemasan dan menumbuhkan rasa percaya diri, (6) Meningkatkan motivasi belajar, sikap dan tingkah laku yang positif serta meningkatkan prestasi belajarnya. (Agustina, 2017a) juga menyatakan Pada saat melaksanakan kegiatan Take and Givesiswa juga meningkatkan keterampilannya dalam bersosilalisasi dan berkomunikasi dengan teman sekelasnya. Sependapat dengan (Anjani, 2015) yang berjudul Penerapan Model Take And Give Dengan Media Grafis Dalam Peningkatan Pembelajaran IPS

Kedua, karena penggunaan media question card. Media question card juga memberikan pengaruh yang baik terhadap kompetensi pengetahuan PPKn siswa karena dalam penggunaan media question card ini siswa dituntut untuk sigap dan mampu berpikir kritis dalam membaca petunjuk maupun maksud dari perasalahan yang ada pada meida question card. Sehingga dalam proses pembelajaran siswa menjadi antusias. Hal ini sejalan dengan pendapat (Kadarwati, 2015) media question card membantu melatih konsentrasi serta daya ingat siswa sehingga siswa harus siap pada saat guru menunjukan media question card sehingga siswa akan berfokus pada guru serta berkonsentrasi dalam menangkap pesan yang terdapat dalam media question card. Hal ini juga sejalan dengan pendapat (Febrianti, 2017) bahwa media question card dapat melatih kesiapan siswa dalam keadaan apapun serta dapat melatih konsentrasi siswa dalam proses pembelajaran, media question card juga dapat menarik perhatian siswa karena di dalam pertanyaan-pertanyaan juga berisikan gambar-gambar. (Wirati, 2014) Media Question Card dalam pembelajaran, yaitu memberikan siswa pertanyaan-pertanyaan melalui kartu yang diberikan oleh guru pada saat pelajaran berlangsung. Kartu pembelajaran yang digunakan untuk pembelajaran berupa pesan tertulis atau gambar Kartu-kartu yang digunakan oleh siswa diberikan warna-warna yang menarik menggunakan tulisan-tulisan yang menarik pula. Siswa yang memperoleh kartu pertanyaan tersebut akan mempunyai ketertarikan dan berusaha untuk menjawab pertanyaan yang terdapat di media question card.

Ketiga, kombinasi penerapan model Take and Give berbantuan media question card yang berdampak pada pembelajaran PPKn, siswa sangat rileks dalam proses pembelajaran karena dalam proses pembelajaran siswa dapat berinteraksi dan bekerjasama dengan kelompoknya dengan saling 
bertukar pikiran, kemudian dibantu dengan media question card yang dapat menarik perhatian siswa dan juga dapat melatih konsentrasi siswa dalam proses pembelajaran. Hal ini juga dinyatakan oleh (Agustina, 2017) Pada saat melaksanakan kegiatan Take and Gives iswa juga meningkatkan keterampilannya dalam bersosilalisasi dan berkomunikasi dengan teman sekelasnya. Model Take and Give lebih mudah diterapkan apabila dipadukan dengan media Question Card. (Wulandari, 2017) menyatakan bahwa media question card dapat menarik perhatian siswa serta membuat siswa berfikir kritis dan aktif dalam proses pembelajaran., (Ikawati, 2017) dalam penelitiannya menyatakan bahwa penerapan model pembelajaran tipe Take ang Give dapat mempengaruhi suatu proses pembelajaran dan juga meningkatkan hasil belajar siswa. Pembeda dalam penelitian ini yaitu terletak pada penggunaan model take and Give serta penggunaan media Question Card yang berdampak pada kompetensi pengetahuan PPKn.

Hasil penelitian ini juga diperkuat dengan penelitian yang sudah dilakukan oleh (Septina, 2017), menyatakan bahwa terdapat pengaruh yang signifikan dalam penerapan model pembelajaran Take and Give terhadap peningkatan hasil belajar mata pelajaran matematika siswa SD kelas 2. Penelitian yang dilakukan oleh (Pariawan, 2012) menyatakan bahwa terdapat pengaruh penerapan model pembelajaran take and give berbasis resolusi konflik terhadap hasil belajar IPS siswa kelas V. Penelitian yang dilakukan oleh (Ardani, 2014), menyatakan bahwa terdapat perbedaan yang signifikan hasil belajar IPS antara siswa yang dibelajarkan dengan model pembelajaran kooperatif tipe Teams Games Tournament (TGT) berbantuan media question card dengan siswa yang dibelajarkan dengan pembelajaran konvensional di kelas V SD. Penelitian yang dilakukan (Herma Yunita HY, 2012) yang Berjudul Penerapan Model Pembelajaran Aktif Take And Give Dalam Pembelajaran Biologi menunjukan adanya peningkatan hasil belajar. (Putri, 2019) yang menyatakan bahwa terdapat perbedaan kompetensi pengetahuan IPA anatara siswa yang dibelajarkan dengan model pembelajaran Group Investigation berbantuan media Question Card. Penelitian yang dilakukan (Anjani, 2015) yang berjudul Penerapan Model Take And Give Dengan Media Grafis Dalam Peningkatan Pembelajaran IPS. Penelitian yang dilakukan (Mutia, 2018) menyatakan terdapat pengaruh yang signifikan dari model pembelajaran take and give terhadap hasil belajar IPA kelas V SD..

\section{KESIMPULAN}

Berdasarkan hasil analisis data Kompetensi Pengetahuan pada kelompok sampel diperoleh thitung= 8,835 sedangkan pada taraf alpha 0,05 dengan $\mathrm{dk}=76$ diperoleh nilai ttabel $=1,992$. Karena thitung > ttabel $(8,835>1,992)$ maka Ha diterima sehingga dapat disimpulkan bahwa Model Take and Give Berbantuan Media Question card berpengaruh terhadap Kompetensi Pengetahuan dalam pembelajaran PPKn Kelas V Gugus Letda Made Putra Tahun Ajaran 2019/2020. Adapun rekomendasi yang dapat disampaikan sebagai berikut : Kepada siswa hendaknya mengikuti kegiatan pembelajaran dengan baik agar dapat meningkatkan kompetensi pengetahuan PPKn.Kepada Guru Sesuai pengalaman selama penelitian untuk setiap guru jangan penuh ragu dalam menerapkan model - model pembelajaran guna meningkatkan siswa kreatif dalam menyelesaikan persoalan. Kepada Kepala Sekolah Diharapkan melalui hasil penelitian ini dapat dijadikan bahan kebijakan dalam meningkatkan kualitas pembelajaran PPKn yang dilaksanakan oleh guru-guru dan dapat memfasilitasi segala aktivitas belajar siswa. Kepada Peneliti Lain Peneliti bidang sejenis yang memiliki kesamaan baik variabel bebas, varibel terikat ataupun melanjutkan penelitian ini agar hasil penelitian ini nantinya dapat menjadi referensi ataupun penelitian yang relevan.

\section{DAFTAR PUSTAKA}

Agustina. (2017a). Model Pembelajaran Take and Give Berbasis kebudayaan Lokal TerhadapHasil Belajar PPKn Kelas V SD. MIMBAR PGSD Ejournal Undiksha, 5(2).

Agustina. (2017b). PENGARUH MODEL PEMBELAJARAN TIPE TAKE AND GIVE BERBASIS PENDIDIKAN KARAKTER TERHADAP MOTIVASI DAN HASIL BELAJAR SISWA DALAM PEMBELAJARAN KIMIA. JPI (Jurnal Pendidikan Indonesia), 2(1).

Anjani. (2015). berjudul Penerapan Model Take And Give Dengan Media Grafis Dalam Peningkatan Pembelajaran IPS. E-Journal PGSD Universitas Pendidikan Ganesha, 3(1).

Ardani. (2014). Pengaruh Model Kooferatif TGT Berbantuan Question Card terhadap hasil Belajar Ips. Siswa Kelas V. Jurnal Pgsd, 2(1). 
Ariswati, N. P. E. A. (2018). Pengaruh Model Pembelajaran Problem Based Learning Terhadap Hasil Belajar Matematika Siswa Kelas V Sd Negeri Nanggulan. PGSD Universitas Pendidikan Ganesha Mimbar PGSD, 6(4). https://doi.org/10.1590/s1809-98232013000400007

Arsyad, A. (2017). Media Pembelajaran. PT. Rajagrafindo Persada.

Darmadi. (2015). Urgensi Pendidikan Pancasila dan Kewarganegaraan di Perguruan Tinggi.

Dewi. (2014). Model Pembelajaran Take And Give Berbantuan Media Grafis Terhadap Hasil Belajar PPKn SD. MIMBAR PGSD Ejournal Undiksha, 2(1).

Exma. (2016). Give Type to Improve Students Learning Results in Sosiology Subject at Class XI IIS 4 SMA Negeri 2 Surakarta. MIMBAR PGSD Ejournal Undiksha, 3(1).

Febrianti, I. (2017). , Susilo Tri Widodo. Jurnal Kreatif, 14692(September 2017), 172-179.

Herma Yunita HY. (2012). Penerapan Model Pembelajaran Aktif Take And Give Dalam Pembelajaran Biologi menunjukan adanya peningkatan hasil belajar. MIMBAR PGSD Ejournal Undiksha, 3(1).

Huda, M. (2013). media pembelajaran.

Ikawati. (2017). penerapan model pembelajaran tipe Take ang Give dapat mempengaruhi suatu proses pembelajaran dan juga meningkatkan hasil belajar siswa. MIMBAR PGSD Ejournal Undiksha, 3(2).

Kadarwati. (2015). KEEFEKTIFAN METODE ETH BERBANTUAN MEDIA QUESTION CARD TERHADAP HASIL BELAJAR PKn. E-Journal PGSD Universitas Pendidikan Ganesha, 3(1).

Kosasih. (2016). Strategi Belajar dan Pembelajaran implementasi Kurikulum 2013. Yrama Widya.

Lantanida. (2014). Pengaruh Model Pembelajaran Take And Give Terhadap Hasil Belajar Ipa Kelas V SD. MIMBAR PGSD Ejournal Undiksha, 4(2).

Mutia. (2018). Pengaruh Model Pembelajaran Take and Give Terhadap Hasil Belajar IPA kelas V SD. Mimbar PGSD Universitas Pendidikan Ganesha, 1(1).

Pariawan. (2012). pengaruh penerapan model pembelajaran take and give berbasis resolusi konflik terhadap hasil belajar IPS siswa kelas V. E-Journal PGSD Universitas Pendidikan Ganesha, 2(1).

Parlina. (2017). PENGARUH MODEL PEMBELAJARAN TAKE AND GIVE. BERBASIS RESOLUSI KONFLIK TERHADAP HASIL BELAJAR IPS. E-Journal PGSD Universitas Pendidikan Ganesha, 3(1).

Putri, N. K. I. P. (2019). Pengaruh Model Pembelajaran Group Investigation Berbantuan Media Questions Card Terhadap Pemahaman Konsep \dan Keterampilan Berpikir Kritis IPA. Thinking Skills and Creativity Journal, 1(2), 46. https://doi.org/10.23887/tscj.v1i2.20492

Rahayu. (2018). PENGARUH MODEL QUANTUM TEACHING BERBASIS TRI HITA KARANA TERHADAP KOMPETENSI PENGETAHUAN PPKN SISWA KELAS V. MIMBAR PGSD Ejournal Undiksha, 2(1).

Sari dan Tarigan. (2017). Pengaruh Model Pembelajaran Take and Give Terhadap Keterampilan Proses Sains Siswa Kelas V. MIMBAR PGSD Ejournal Undiksha, 2(1).

Septina. (2017). pengaruh yang signifikan dalam penerapan model pembelajaran Take and Give terhadap peningkatan hasil belajar mata pelajaran matematika siswa SD kelas 2. E-Journal PGSD Universitas Pendidikan Ganesha, 2(1).

Shoimin, A. (2014). Model Pembelajaran Inovatif Dalam Kurikulum 2013. Ar-Ruzz Media.

Theriana. (2019). Pengaruh Model Pembelajaran Take and Give terhadap Hasil Belajar siswa pada mata pelajaran Bahasa Inggris di SD IT Qurota'ayun Belitang OKU Timur. Scholastica Journal, 2(1). 
Udayantri. (2017). Penerapa Metode Take And Give untuk Meningkatkan hasil Belajar IPA Siswa Kelas IV 6. Mimbar PGSD Universitas Pendidikan Ganesha, 2(1).

Viani. (2017). model pembelajaran course review horay berbatuan media question cards berpengaruh terhadap hasil belajar matematika siswa kelas IV SD. MIMBAR PGSD Ejournal Undiksha, 2(1).

Wirati. (2014). PENGARUH MODEL PEMBELAJARAN KOOPERATIF TAKE AND GIVE TERHADAP PENINGKATAN HASIL BELAJAR MATERI PERKALIAN SISWA KELAS 2 SD N DEMANGAN YOGYAKARTA. E-Journal PGSD Universitas Pendidikan Ganesha, 3(1).

Wiyasa. (2015). Pengaruh Model Pembelajaran Open Ended Berbasis Penilaian proyek teradap kompetensi Pengetahuan PPKn Siswa. E-Journal PGSD Universitas Pendidikan Ganesha, 3(1).

Wulandari. (2017). Penggunaan Question Card Dalam Model Pembelajaran Pbl Dan Problem Solving Terhadap Hasil Belajar Matematika. EKUIVALEN - Pendidikan Matematika, 28(1).

Yuliastini. (2015). Pengaruh Model Take and Give Berbantuan Multimedia interaktif Terhadap Hasil Belajar IPS. E-Journal PGSD Universitas Pendidikan Ganesha, 3(1) 